\title{
Geographic shifts in climatically suitable areas and loss of genetic variability under climate change in a neotropical tree
}

\author{
Jose Alexandre Diniz-Filho ${ }^{1 *}$, Rosane Collevatti ${ }^{2}$, Lázaro Chaves $^{3}$, Thannya Soares ${ }^{2}$, João Carlos Nabout ${ }^{4}$, \\ Thiago Fernando Rangel ${ }^{5}$, Dayane Melo ${ }^{6}$, Jacqueline Lima ${ }^{7}$, Mariana Telles ${ }^{2}$ \\ From IUFRO Tree Biotechnology Conference 2011: From Genomes to Integration and Delivery \\ Arraial d'Ajuda, Bahia, Brazil. 26 June - 2 July 2011
}

\section{Background}

Many species are expected to suffer a strong shift in geographic ranges due to climate changes in the next fifty years, depending on their ecological tolerance and current demographical parameters, which were in turn shaped by their evolutionary history. These shifts may also cause a change in genetic population structure and variability, because local extinctions or reduction in fitness are not expected to be random in geographical space. Here we used an ensemble forecast approach of Species Distribution Modeling (SDM hereafter, also known as niche modeling) to derive current and future geographic distribution of the Neotropical tree Dipteryx alata ("Baru" tree, Fabaceae). We then obtained a series of genetic parameters for the species after generating extinctions in areas of low future habitat suitability.

\section{Methods}

We obtained a total of 448 occurrences of D. alata throughout the Brazilian Cerrado, which were recorded in a grid with 6240 cells of $0.5^{\circ}$ of latitude/longitude covering South America. These occurrences were modeled as a function of eight climatic variables (WORLDCLIM), for the current time and projected into2050,for three different Global Circulation Models (AOGCMs CCCma, Csiro, HadCm3) [1,2].

Occurrences were modeled using six different SDM techniques [3]. Methods used were BIOCLIM, Euclidian, Gower and Mahalanobis distances, GARP and MAXENT. For each of these methods, models were built using 255 combinations of the climatic variables, each

\footnotetext{
* Correspondence: diniz@icb.ufg.br

'Departamento de Ecologia, ICB, Universidade Federal de Goiás, Brazil Full list of author information is available at the end of the article
}

one tested using 50 cross-validations using True-Skill statistics (models with TSS $<0.7$ were excluded). A Principal Component Analysis (PCA) of the estimated frequencies of occurrence, obtained by SDMs and AOGCMs, was used to compare the maps. Variance components of these sources were obtained and mapped [2].

Genetic data for D. alata consisted in microsatellites markers analyzed for 25 widely distributed local populations, encompassing species' geographical range. A total of 644 individual trees were genotyped for eight microsatellite loci. Genetic parameters were used to estimate the total amount of polymorphism and genetic diversity currently found in D. alata. We estimated the number of alleles per locus, genetic diversity (expected heterozygosity under Hardy-Weinberg equilibrium), and the expected heterozygosity under mutation-drift equilibrium. Moreover, we recalculated these parameters by assuming that, under climate change, there will be a displacement of climatically suitable areas for the species and, consequently, that only populations found in regions above certain levels of suitability in the future will persist.

\section{Results and discussion}

The ensemble forecasting approach reveals that $D$. alata will shift its geographic range and climatically suitable areas from Central towards Southeastern Brazil (Fig. 1). The first principal component explains $74.3 \%$ of the variation among maps and, on average, $95 \%$ of the variation among them is due to SDMs used.

The changes in the climatically suitable areas in $D$. alata imply a reduction in the genetic parameters. The parameters remain approximately constant up to a 


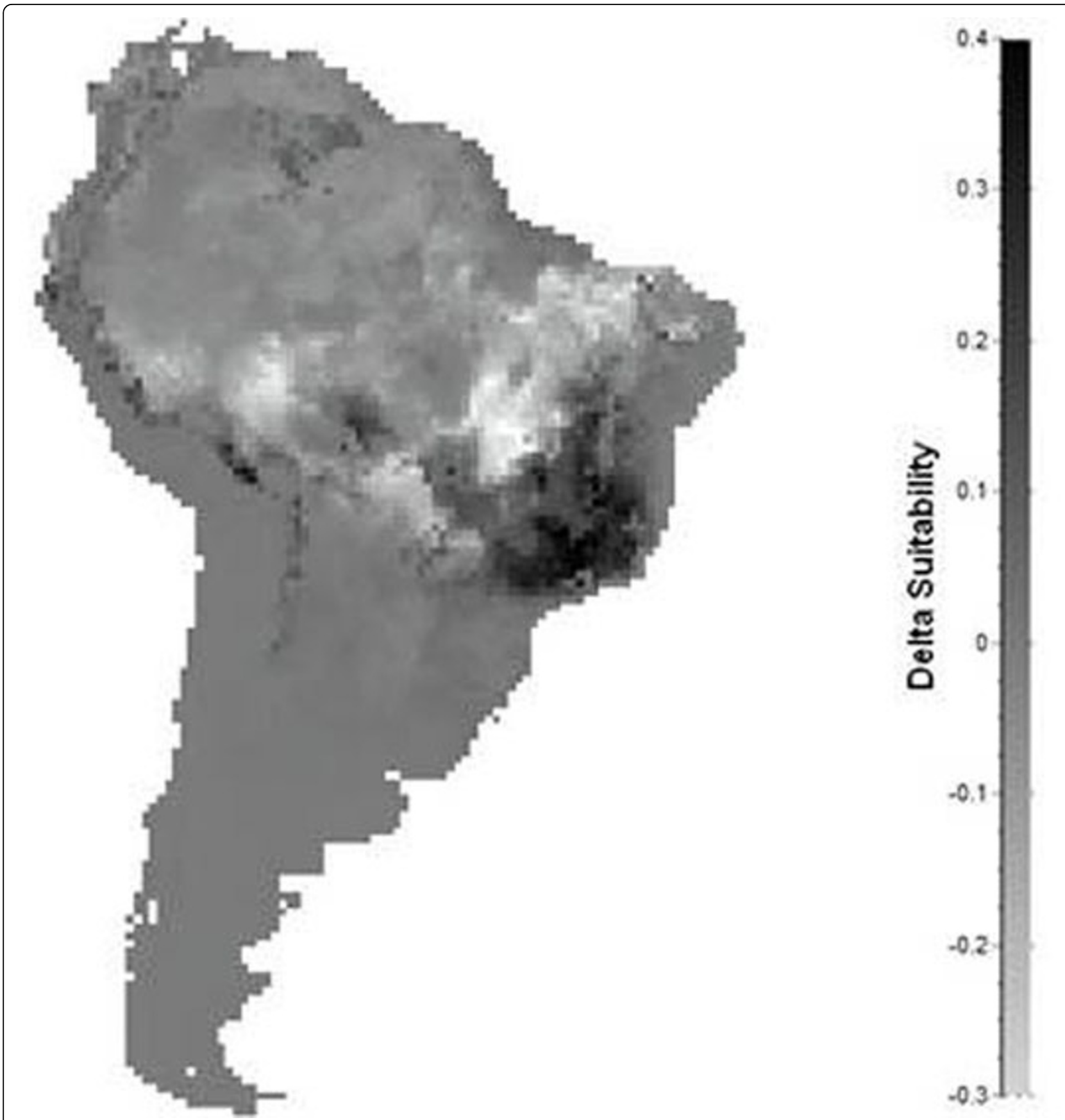

Figure 1 Shifts of climatically suitable areas in 2050 for Dipteryx alata, expressing change in estimated frequency of occurrences of the species based on six species distribution models projected into three GCMs.

$50 \%$ threshold, which is the minimum by assuming a majority consensus of frequency of occurrences. However, after this critical threshold there is an abrupt reduction in all parameters, although the magnitude of shift is only about $10 \%$ of the current values, on average (Fig. 2). There is a wide variation of shifts direction and magnitude among loci for each parameter, and actually these trends are usually driven by two or three loci.
The wide current range and ecological tolerance of $D$. alata explains why low levels of loss in genetic diversity were observed here, contrasting with previous results for other species (i.e., the "pequi" tree Caryocar Braziliense). Because of the wide range, currently and in the future, some of the local populations with highest genetic diversity will potentially remain in highly suitable areas in the future, even using very conservative thresholds of $80 \%$. 


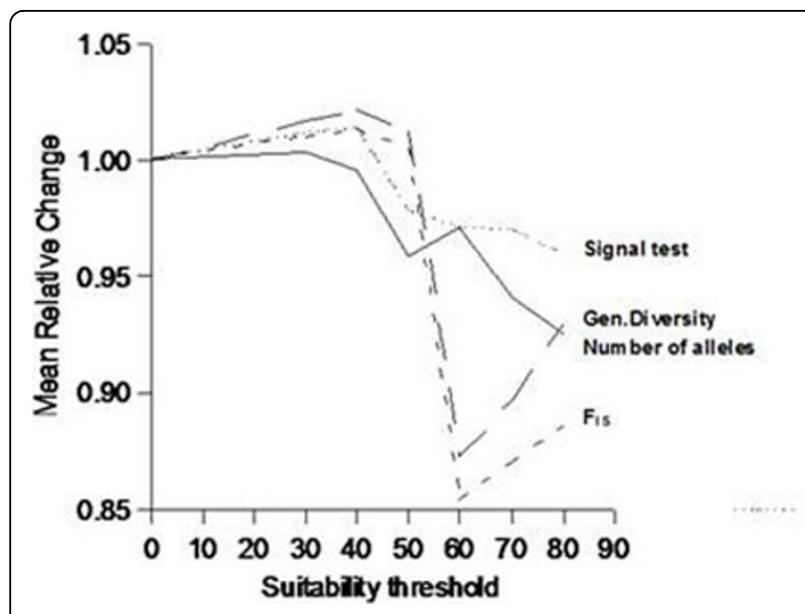

Figure 2 Reduction in genetic parameters of $D$. alata estimated at increasingly levels of environmental suitability estimated for 2050.

However, it is important to highlight that coalescence analyses and the expected heterozygosity under mutation-drift equilibrium suggest strong population bottlenecks for the species in the recent past, which were corroborated by hind cast projections of the SDMs using paleoclimatic data. This explains the low level of genetic variability in $D$. alata, despite its wide geographic range.

Thus, despite the shift in geographic range size and climatically suitable areas towards Southeastern Brazil and the expected downward shift in the genetic parameters, the analyses performed here do not show a strong loss of genetic diversity in D. alata. Even so, it is important to realize that these results are mainly due to the relatively low current genetic variability of the species, probably associated with recent population bottlenecks. In this case, climatic shifts can have more serious adaptive consequences and further investigations are necessary to avoid a false indicative of high probability of persistence of this species based on a low relative level of loss of genetic diversity.

\footnotetext{
Author details

'Departamento de Ecologia, ICB, Universidade Federal de Goiás, Brazil. ${ }^{2}$ Departamento de Blologia Geral, ICB, UFG, Brazil. ${ }^{3}$ Escola de Agronomia \& Engenharia de Alimentos, UFG, Brazil. ${ }^{4}$ UnUCET, Universidade Estadual de Goiás, Brazil. ${ }^{5}$ Departamento de Ecologia, ICB, UFG, Brazil. ${ }^{6}$ Programa de PósGraduação em Agronomia, UFG, Brazil. PPrograma de Pós-Graduação em Ecologia \& Evolução, UFG, Brazil.
}

Published: 13 September 2011

\section{References}

1. Araújo MB, New M: Ensemble forecasting of species distributions. Trends in Ecology and Evolution 2007, 22:42-47.

2. Diniz-Filho JAF, Bini LM, Rangel TF, Loyola RD, Hof C, Nogues-Bravo D, Araújo MB: Partitioning and mapping uncertainties in ensembles of forecasts of species turnover under climate change. Ecography 2009, 32:897-906.
3. Elith J, Graham CH: Do they? How do they? Why do they differ? On finding reasons for differing performances of species distribution models. Ecography 2009, 32:66-77.

doi:10.1186/1753-6561-5-S7-O4

Cite this article as: Diniz-Filho et al.: Geographic shifts in climatically suitable areas and loss of genetic variability under climate change in a neotropical tree. BMC Proceedings 2011 5(Suppl 7):O4.
Submit your next manuscript to BioMed Central and take full advantage of:

- Convenient online submission

- Thorough peer review

- No space constraints or color figure charges

- Immediate publication on acceptance

- Inclusion in PubMed, CAS, Scopus and Google Scholar

- Research which is freely available for redistribution

Submit your manuscript at www.biomedcentral.com/submit 